Louisiana State University

LSU Digital Commons

$12-1-2017$

\title{
Species Identification of Vagrant Empidonax Flycatchers in Northeastern North America Via Non-Invasive DNA Sequencing
}

Nathan R. Goldberg

Cornell Lab of Ornithology

Nicholas A. Mason

Cornell Lab of Ornithology

Follow this and additional works at: https://digitalcommons.Isu.edu/biosci_pubs

\section{Recommended Citation}

Goldberg, N., \& Mason, N. (2017). Species Identification of Vagrant Empidonax Flycatchers in Northeastern North America Via Non-Invasive DNA Sequencing. Northeastern Naturalist, 24 (4), 499-504. https://doi.org/10.1656/045.024.0408 


\section{BioOne COMPLETE}

\section{Species Identification of Vagrant Empidonax Flycatchers in Northeastern North America Via Non-Invasive DNA Sequencing}

Authors: Goldberg, Nathan R., and Mason, Nicholas A.

Source: Northeastern Naturalist, 24(4) : 499-504

Published By: Eagle Hill Institute

URL: https://doi.org/10.1656/045.024.0408

BioOne Complete (complete.BioOne.org) is a full-text database of 200 subscribed and open-access titles in the biological, ecological, and environmental sciences published by nonprofit societies, associations, museums, institutions, and presses.

Your use of this PDF, the BioOne Complete website, and all posted and associated content indicates your acceptance of BioOne's Terms of Use, available at www.bioone.org/terms-of-use.

Usage of BioOne Complete content is strictly limited to personal, educational, and non - commercial use. Commercial inquiries or rights and permissions requests should be directed to the individual publisher as copyright holder.

BioOne sees sustainable scholarly publishing as an inherently collaborative enterprise connecting authors, nonprofit publishers, academic institutions, research libraries, and research funders in the common goal of maximizing access to critical research. 


\title{
Species Identification of Vagrant Empidonax Flycatchers in Northeastern North America via Non-invasive DNA Sequencing
}

\author{
Nathan R. Goldberg ${ }^{1, *}$ and Nicholas A. Mason ${ }^{1}$
}

\begin{abstract}
Vagrant individuals from cryptic species complexes pose a persistent challenge for accurate species identification, hindering our understanding of vagrancy in these taxa. Here, we used non-invasive sampling of fecal matter to sequence the ND2 mitochondrial gene of 2 vagrant western flycatchers observed in northeastern North America. The DNAsequence data we recovered from these vagrants fell within a clade of known Empidonax difficillis (Pacific-slope Flycatcher) haplotypes. Our work provides robust records of 2 vagrant Pacific-slope Flycatchers in the northeastern US. These findings illustrate the power of non-invasive sampling for species identification of vagrants from cryptic species complexes.
\end{abstract}

\section{Introduction}

Vagrant birds that occur far outside of their expected geographic distribution provide excellent opportunities to explore patterns of dispersal, demography, and changing distributions (Lees and Gilroy 2009, Veit 2000). In North America, vagrant birds are found throughout the year, though most occur in the fall when many $1^{\text {st }}$-year birds deviate from migratory routes (Thorup et al. 2012). Patterns of avian vagrancy in continental North America are complex; while displacement of immature birds plays a key role, observer bias further complicates our understanding of vagrancy among species (Rondinini et al. 2006). Vagrancy patterns are particularly difficult to study in cryptic species complexes-such as some of the Empidonax flycatchers - in which closely related species are difficult or impossible to identify in the field based on phenotypes alone (Bickford et al. 2007, Novitch et al. 2015).

One method that can help identify vagrant individuals from cryptic species complexes is non-invasive, opportunistic sampling of genetic material (Taberlet and Luikart 1999, Waits and Paetkau 2005). Molecular tools for species identification are generally straightforward to apply, yet only a few studies have employed noninvasive techniques for sampling. Species identification of Michigan's first state record of Tyrannus melancholicus (Vielliot) (Tropical Kingbird; Lindsay and Haas 2013) as well as the confirmation of Britain's first Empidonax virescens (Vielliot) (Acadian Flycatcher; Rare Bird Alert 2015) demonstrate the efficacy of noninvasive sampling and DNA sequencing for species identification.

In this study, we used non-invasive DNA sequencing to determine the species identity of 2 vagrant western flycatchers found in northeastern North America. In

${ }^{1}$ Fuller Evolutionary Biology Program, Cornell Lab of Ornithology, 159 Sapsucker Woods Road, Ithaca, NY, 14850. "Corresponding author-nrg29@cornell.edu.

Manuscript Editor: Adrienne Kovach 
both cases, these flycatchers were discovered by birders in public locations where traditional collecting of a whole specimen would have been difficult. Identifying western flycatchers to species level is difficult in the field: E. difficilis Baird (Pacific-slope Flycatcher) and E. occidentalis Nelson (Cordilleran Flycatcher) can only be confidently identified by vocalizations, morphological measurements of birds in the hand, or DNA (Rush et al. 2009). Consequently, individuals from this cryptic species complex found far from their native ranges are rarely identified with confidence; instead, they are typically recorded simply as "western flycatchers". Prior to this study, there have been 2 records of Pacific-slope Flycatchers, no records of Cordilleran Flycatcher, and 10 records of western flycatchers in northeastern North America (Fig. 1). These species identifications were based on vocal and morphological observations of live birds, and were subsequently vetted by elected reviewers that maintain regional checklists of bird species in each state.

\section{Methods}

On 22 November 2015, N. Goldberg observed a western flycatcher in Central Park, New York City, NY, which defecated while under observation. Goldberg opportunistically collected the excretion on a leaf. J. Hough, New Haven, CT, pers. comm.) found a western flycatcher on 22 December 2015 in a schoolyard in Branford, CT, and similarly collected a fecal sample. Both samples were subsequently stored at $-20{ }^{\circ} \mathrm{C}$ until processing. In addition to fecal samples, a colleague opportunistically recorded the vocalizations of the Central Park bird in Central Park, NY

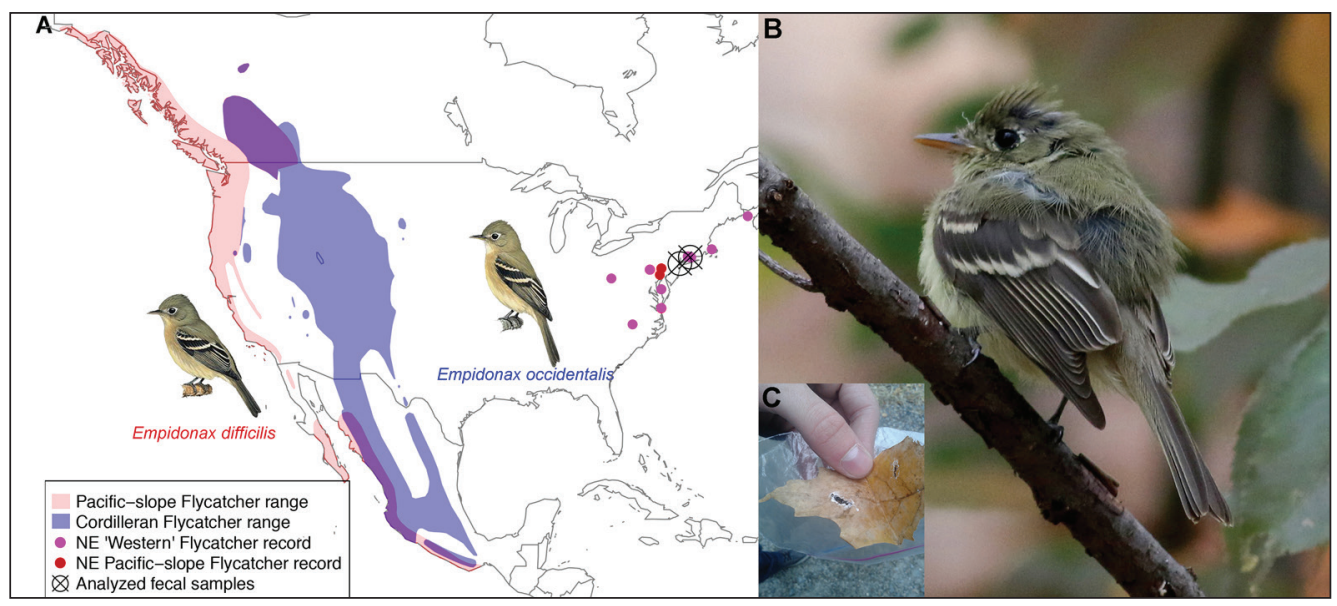

Figure 1. (A) Occurrence records (dots) of Pacific-slope and "Western" flycatchers (Empidonax sp.) for eastern North America taken from eBird.org overlaid on range maps taken from BirdLife International (BirdLife International and NatureServe 2015). Shaded areas correspond to Pacific-slope Flycatcher range, Cordilleran Flycatcher range, and areas of overlap between the species. Localities of vagrant individuals are shown with hatched circles. Plates are reproduced courtesy of Lynx Edicions. (B) Photograph of heretofore unidentified vagrant individual from New York City's Central Park (Photo (C) Jay McGowan). (C) Fecal sample collected from vagrant individual in Central Park (Photo (C) Alex Lees). 
(J. McGowan, Cornell Lab of Ornithology, Ithaca, NY, pers. comm.), which we compared to vocalizations of known Pacific-slope and Cordilleran Flycatchers to complement our genetic analysis.

For the DNA analysis, we extracted genomic DNA from the fecal sample with a QIAamp DNA Stool Kit (Qiagen, Valencia, CA). Prior to digestion, we homogenized each sample in $300 \mu \mathrm{L}$ of Buffer ASL with a TissueRuptor (Qiagen, Valencia, CA). Following homogenization, we added the remaining $1.3 \mathrm{~mL}$ Buffer ASL for a total volume of $1.6 \mathrm{~mL}$, added $20 \mu \mathrm{L}$ 1M DTT and $20 \mu \mathrm{L}$ Proteinase K, and digested the samples on a rotating column overnight in an incubator set to 56 ${ }^{\circ} \mathrm{C}$. These protocol modifications yielded consistently usable amounts of DNA for downstream Sanger sequencing ( $>1$ ng total yield).

For comparison, we downloaded existing ND2 sequences from 37 Pacificslope Flycatcher and 14 Cordilleran Flycatcher individuals from continental North America (Rush et al. 2009). We aligned all sequences using ClustalW (Thompson et al. 1994) with default settings in Geneious v6.1.6 (Kearse et al. 2012). We designed a primer pair from the consensus sequence of the multi-species alignment to target a 302-nucleotide region of ND2, which corresponds to positions L5176 (5' AGCTCTAGGAGGGTGAATAGG 3') and H5414 (5' CGAGCGATAGAAGAGCAAGTATAA 3') in the Gallus gallus domesticus L. (Domestic Chicken) mtDNA genome (GenBank X52392; Desjardins and Morais 1990). This region included 3 single-nucleotide polymorphisms that differentiate the Pacific-slope Flycatcher and the Cordilleran Flycatcher (Rush et al. 2009). We amplified the target region using Q5 High-fidelity DNA Polymerase (New England BioLabs, Ipswich, MA) with $\sim 1$ ng of template DNA. We denatured the DNA for $30 \mathrm{sec}$ at $98{ }^{\circ} \mathrm{C}$, performed 30 PCR cycles with $98{ }^{\circ} \mathrm{C}$ denaturation for $5 \mathrm{sec}, 58{ }^{\circ} \mathrm{C}$ annealing for $20 \mathrm{sec}, 72{ }^{\circ} \mathrm{C}$ elongation for $25 \mathrm{sec}$, and a final elongation step at $72{ }^{\circ} \mathrm{C}$ for $2 \mathrm{~min}$. We performed an ExoSap PCR product clean-up using Exonuclease I (10 units $\mu \mathrm{L})$ and Shrimp Alkaline Phosphase (1 unit/ $\mu \mathrm{L})$ and sequenced the resulting fragments on an ABI 3730xl automatic DNA sequencer (Applied Biosystems, Foster City, CA).

Upon receiving the raw sequencing output, we examined chromatograms in Geneious and created a consensus sequence for each unique product by comparing the forward or reverse reads. We trimmed the alignment to a 272-bp region with no missing data. These edited sequences (GenBank Accession Numbers KX808581 and KX808582) were then compared to the 51 preexisting ND2 sequences of Empidonax flycatchers from Rush et al. (2009). We constructed a haplotype network based on uncorrected pairwise DNA sequence distances under an infinite sites model, using the pegas package (Paradis et al. 2004) in R (R Core Team 2016).

\section{Results and Discussion}

We found 12 unique haplotypes for the ND2 coding region among the 53 Empidonax flycatchers examined in this study (Fig. 2). The maximum uncorrected genetic distance among haplotypes was $1.8 \%$, and a minimum of 2 mutations separated haplotypes of Pacific-slope Flycatcher and Cordilleran Flycatcher generated by previous studies (Rush et al. 2009). These 2 species are reciprocally monophyletic 
in mtDNA. The haplotypes representing the 2 fecal samples of vagrant Empidonax sequenced in this study are embedded within the existing Pacific-slope Flycatcher haplotypes and are divergent from Cordilleran Flycatcher.

We also compared the recording made in Central Park to existing recordings of Pacific-slope and Cordilleran Flycatchers (Fig. 3). Qualitatively, the recorded call note matches known Pacific-slope Flycatcher vocalizations. This similarity is apparent in the distinctive upwards inflection found during the last third of the note

Figure 2. Haplotype network indicating sequence similarity between the New York City vagrant (red), Connecticut vagrant, Pacific-slope Flycatchers, and Cordilleran Flycatchers. Circle sizes are proportional to the number of individuals with each haplotype. Small black dots represent hypothetical haplotypes that were not sampled in this study.
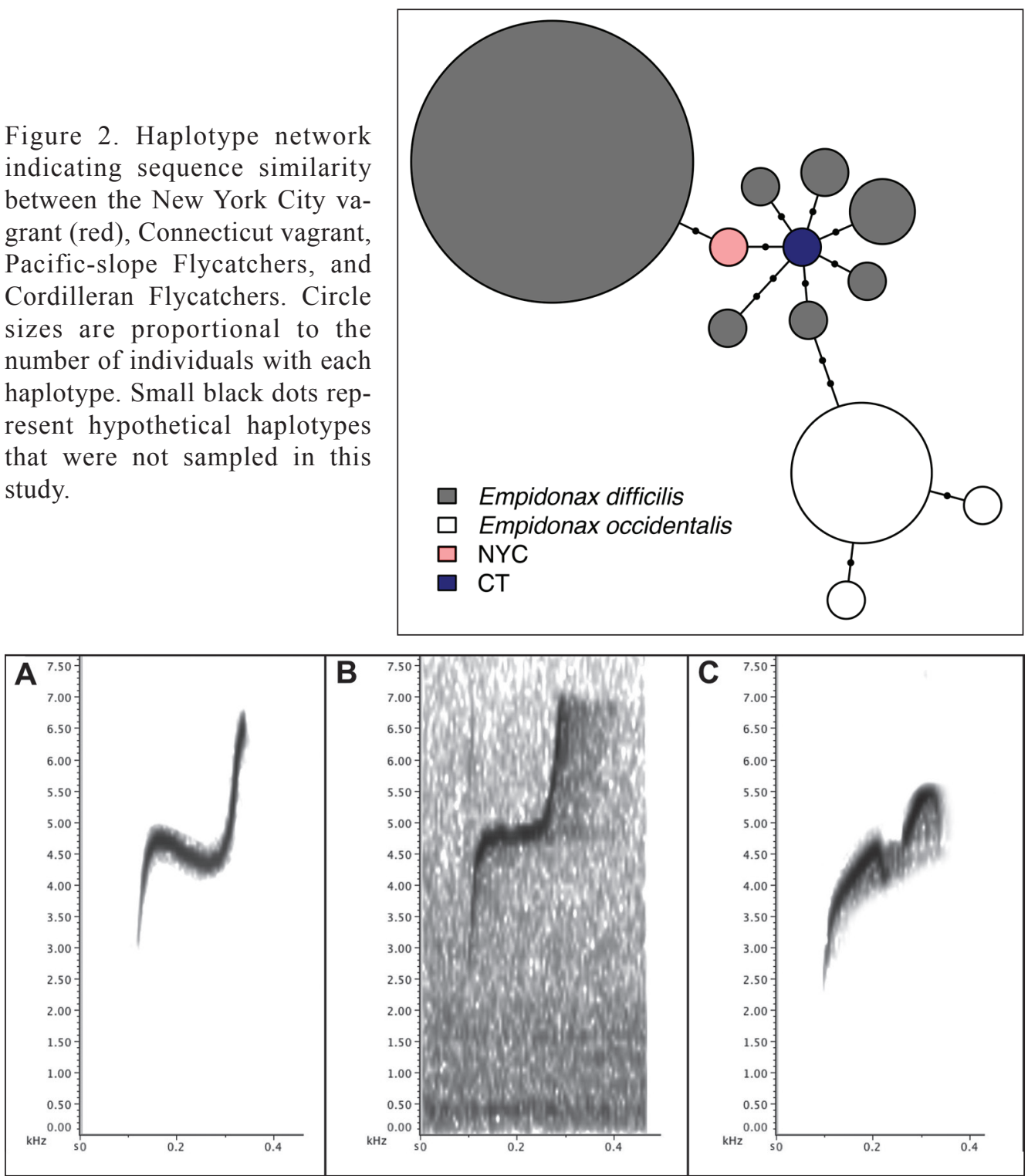

Figure 3. (A) Sonogram of a breeding Pacific-slope Flycatcher ), (B) sonogram of the Central Park vagrant western flycatcher (Empidonax sp.), and (C) sonogram of a breeding Cordilleran Flycatcher. Recordings are courtesy of Macaulay Library (ML 7600, ML 29916831, ML 87920, from left to right). 
(between $\sim 4.5-7.0 \mathrm{kHz}$ ). Furthermore, the call note from the vagrant individual is 1 continuous vocalization, which is characteristic of the Pacific-slope Flycatcher, rather than a 2-part call commonly given by Cordilleran Flycatcher.

The mitochondrial-gene sequences that we obtained from fecal samples of the 2 vagrant Empidonax flycatchers suggest that both individuals are Pacific-slope Flycatchers rather than Cordilleran Flycatchers. We note, however, that mitochondrial-sequence data alone are limited in their power for species identification in certain instances: introgression associated with hybridization and mitochondrial sweeps can preclude accurate identification without nuclear-sequence data (Moritz and Cicero 2004, Toews and Brelsford 2012). In the case of Empidonax flycatchers in North America, hybrid individuals occurring in the Pacific-slope Flycatcher $\mathrm{x}$ Cordilleran Flycatcher contact zone in southwestern Canada all possess mitochondrial Pacific-slope Flycatcher haplotypes (Rush et al. 2009). Therefore, there is a small chance that the individuals included in this study may be hybrids or backcrosses from this contact zone rather than pure Pacific-slope Flycatchers (Rush et al. 2009). For the vagrant individual that occurred in New York City, the recorded vocalization is more similar to the Pacific-slope than Cordilleran Flycatcher, which corroborates our species identification based on mtDNA.

The large number of historical "western" flycatcher records in northeastern North America reflects our inability to confidently identify species in this complex based on field-observations alone. Further observations and sampling of vagrants will help clarify the relative frequency of Pacific-slope Flycatchers and Cordilleran Flycatchers as vagrants. In addition to providing reliable occurrence data and deepening our understanding of vagrant records in northeastern North America, our study highlights the broader utility of non-invasive, molecular methods toward species-level identification of vagrants from cryptic species complexes.

\section{Acknowledgments}

We thank B. Butcher for assistance in optimizing the fecal DNA extraction protocol and other help in the lab. J. Hough and S. Broker provided fecal samples of the Connecticut vagrant individual. We are grateful to $\mathrm{A}$. Lees for discussion of vagrancy and providing the photograph of the fecal sample. J. McGowan recorded the Central Park vagrant and helped generate the figure to compare vocalizations. I. Lovette provided valuable feedback on an earlier version of this manuscript and general support to N.R. Goldberg and N.A. Mason Thanks to the Macaulay Library for providing recordings. Finally, we appreciate the Tracy Family for financial support to allow N.R. Goldberg to carry out this project.

\section{Literature Cited}

Bickford, D., D.J. Lohman, N.S. Sodhi, P.K.L. Ng, R. Meier, K. Winker, K. Ingram, and I. Das. 2007. Cryptic species as a window on diversity and conservation. Trends in Ecology and Evolution 22:148-155.

Desjardins, P., and R. Morais. 1990. Sequence and gene organization of the Chicken mitochondrial genome: A novel gene order in higher vertebrates. Journal of Molecular Biology 212:599-634. 
Kearse, M., R. Moir, A. Wilson, S. Stones-Havas, M. Cheung, S. Sturrock, S. Buxton, A. Cooper, S. Markowitz, C. Duran, T. Thierer, B. Ashton, P. Meintjes, and A. Drummond. 2012. Geneious Basic: An integrated and extendable desktop software platform for the organization and analysis of sequence data. Bioinformatics 28:1647-1649.

Lees, A.C., and J. J. Gilroy. 2009. Vagrancy mechanisms in passerines and near passerines. Pp. 1-23, In Rare birds, Where and When: An Analysis of Status and Distribution in Britian and Ireland. Volume 1: Sandgrouse to New World Orioles. R. Slack (Ed.). Rare Bird Books, York, UK. 500 pp.

Lindsay, A.R., and S. Haas. 2013. DNA from feces and museum specimens confirms a first state-record bird. Occasional Papers of the Museum of Zoology University of Michigan 742:1-10.

Moritz, C., and C. Cicero. 2004. DNA barcoding: Promise and pitfalls. PLoS Biology 2:e354-3.

Novitch, N.R., M. Westberg, and R.M. Zink. 2015. Migration of Alder Flycatchers (Empidonax alnorum) and Willow Flycatchers (Empidonax traillii) through the Tuxtla Mountains, Veracruz, Mexico, and the identification of migrant flycatchers in collections. Wilson Journal of Ornithology 127:142-145.

Paradis, E., J. Claude, and K. Strimmer. 2004. ape: Analyses of phylogenetics and evolution in R language. Bioinformatics 20:289-290.

R Core Team. 2016. R: A language and environment for statistical computing. R Foundation for Statistical Computing, Vienna, Austria. Available online at https://www.r-project. org/. Accessed 26 July 2016.

Rare Bird Alert. 2015. Finders-in-the-field: Acadian Flycatcher, Dungeness, Kent, September 2015. Available online at http://www.rarebirdalert.co.uk/v2/Content/Finders_in_the_Field_Acadian_Flycatcher_Dungeness_Kent_September_2015.aspx?s_ id $=1073328238$. 26 July 2016.

Rondinini, C., K.A. Wilson, L. Boitani, H. Grantham, and H.P. Possingham. 2006. Tradeoffs of different types of species occurrence data for use in systematic conservation planning. Ecology Letters 9:1136-1145.

Rush, A.C., R.J. Cannings, and D.R. Irwin. 2009. Analysis of multilocus DNA reveals hybridization in a contact zone between Empidonax flycatchers. Journal of Avian Biology 40:614-624.

Taberlet, P., and G. Luikart. 1999. Non-invasive genetic sampling and individual identification. Biological Journal of the Linnean Society 68:41-55.

Thompson, J.D., D.G. Higgins, and T.J. Gibson. 1994. CLUSTAL W: Improving the sensitivity of progressive multiple-sequence alignment through sequence weighting, position-specific gap penalties, and weight-matrix choice. Nucleic Acids Research 22:4673-4680.

Thorup, K., T.E. Ortvad, R.A. Holland, J. Rabøl, M.W. Kristensen, and M. Wikelski. 2012. Orientation of vagrant birds on the Faroe Islands in the Atlantic Ocean. Journal of Ornithology 153:1261-1265.

Toews, D.P.L., and A. Brelsford. 2012. The biogeography of mitochondrial and nuclear discordance in animals. Molecular Ecology 21:3907-3930.

Waits, L.P., and D. Paetkau. 2005. Noninvasive genetic sampling tools for wildlife biologists: A review of applications and recommendations for accurate data collection. Journal of Wildlife Management 69:1419-1433.

Veit, R. 2000. Vagrants as the expanding fringe of a growing population. Auk 117:242-245. 